\title{
PENGERTIAN TIPE DATA SUBJANGKAUAN
}

\author{
M.Rian Safei \\ 155100045 \\ Fakultas Komputer \\ m.riansafei.student@umitra.ac.id
}

\begin{abstract}
Subjangkauan merupakan suatu tipe yg menyatakan suatu jangkauan nilai dari suatu tipe yg sudah ada. Jangkauan nilai ditentukan oleh nilai terkecil dan nilai terbesar.Antara nilai terkecil dan nilai terbesar dipisahkan oleh tanda subjangkauan (..).Bentukpendeklarasian:TYPEnama_type=nilai_terkecil...nilai_terbesar;Subjangka uan tdk dapat diterapkan untuk tipe real. Semua tipe ordinal bisa dipakai.

Tipe data ini adalah tipe data yang dapat didefinisikan sendiri oleh pemakai. Nilai data pada tipe ini mempunyai jangkauan tertentu. Misalnya nilai ujian mempunyai harga 0 sampai 100 maka nilai ujian dapat didefinisikan.
\end{abstract}

Kata Kunci : Real dan Ordinal 


\section{A. PENDAHULUAN}

Sesuai dengan namanya, tipe data subrange merupakan tipe data bentukan yang berasal dari bagian (sub) tipe data lain yang berada dalam sebuah jangkauan (range).

Sebagai contoh, kita bisa membatasi sebuah tipe data "satuan" dimana hanya bisa diisi dengan angka 1 hingga 9. Angka 1 sampai dengan 9 merupakan bagian $(s u b)$ dari tipe data integer. Jika kita mencoba mengisi tipe data "satuan" ini dengan angka selain 1-9, Pascal akan memberikan error.

Tidak jarang terjadi batas nilai yang mungkin untuk suatu peubah merupakan bagian (subjangkauan) dari tipe data yang telah didefinisikan

\section{B. PEMBAHASAN / STUDI KASUS}

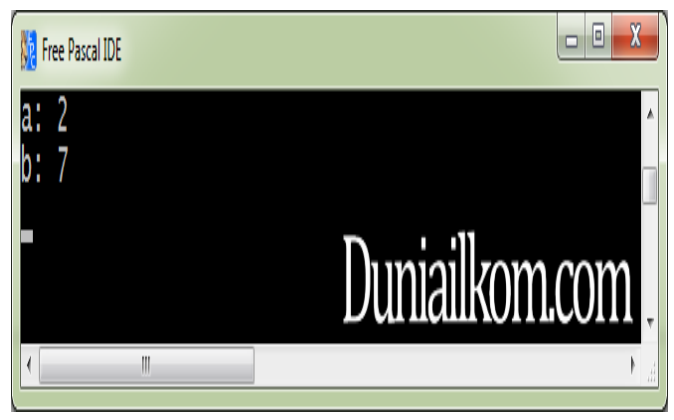

Sama seperti tipe data enumerated, tipe data subrange juga merupakan tipe data yang dibentuk sendiri. Kali ini saya akan membahas lebih dalam tentang pengertian dan cara penggunaan tipe data subrange pascal.
Untuk membuat tipe data subrange, caranya hampir sama dengan tipe data enumerated, dimana kita harus mendefenisikannya di bagian type, kemudan baru membuatnya sebagai variabel di bagian var. Berikut contohnya:

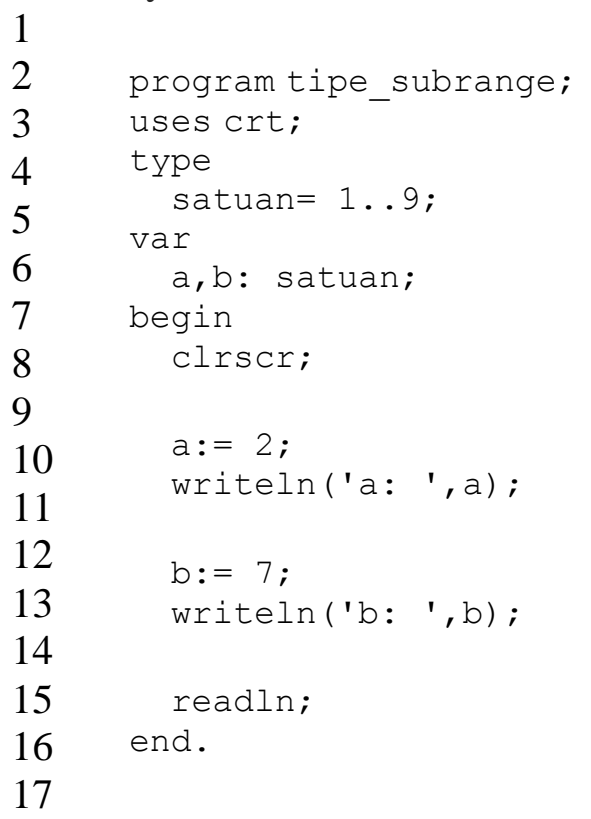

Dalam kode program diatas, saya mendefenisikan sebuah tipe data subrange 'satuan' dengan angka 1 hingga 9. Tanda titik dua '..' digunakan untuk membatasi seberapa jauh jangkauan untuk satuan ini.

Jika saya ingin membuat tipe data 'puluhan' yang terdiri dari angka 11 hingga 99 maka penulisannya adalah sebagai berikut:

1 type

2 satuan= 11..99;

Apa yang terjadi jika kita memberikan angka diluar jangkauan tipe data subrange? Berikut contohnya:

1 program tipe_subrange;

2 uses crt;

3 type 


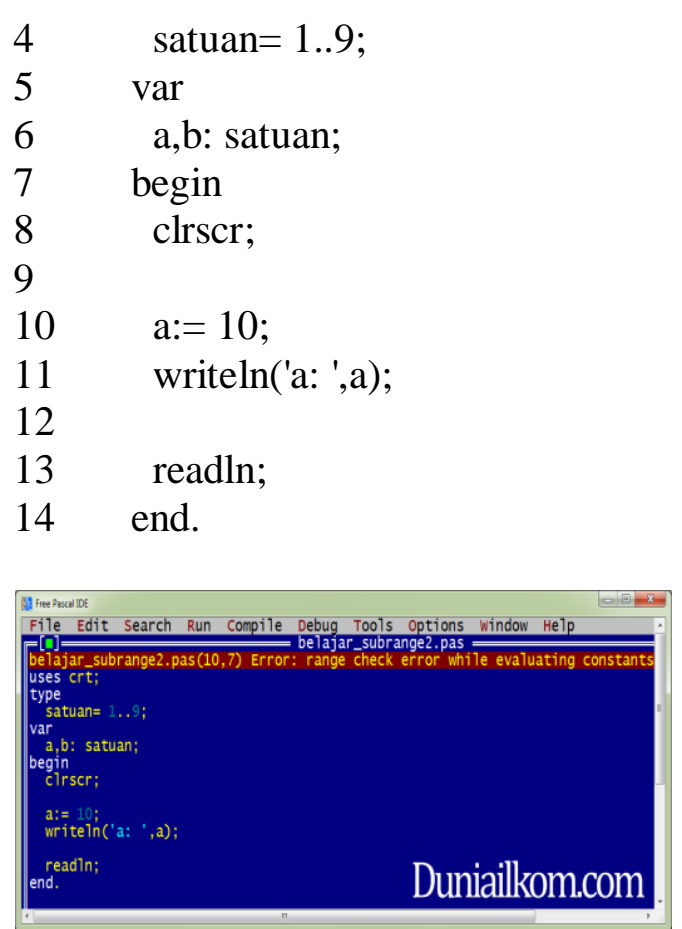

Hasilnya, compiler FreePascal akan menghasilkan error: range check error while evaluating constants, yang artinya nilai tersebut berada di luar range (jangkauan) yang telah ditetapkan, dimana saya mencoba memberikan nilai 10 .

Cara Penggunaan Tipe Data Subrange dari Enumerated

Untuk membuatnya lebih kompleks (dan juga lebih fleksibel), kita bisa membuat tipe data subrange dari yang isinya berasal dari tipe data enumerated. Langsung saja kita masuk ke contoh programnya:

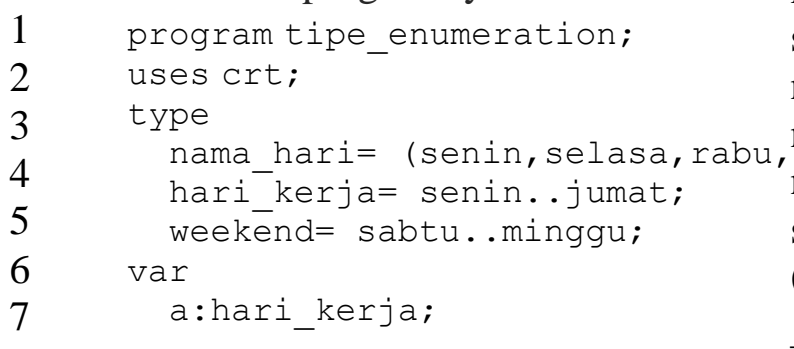

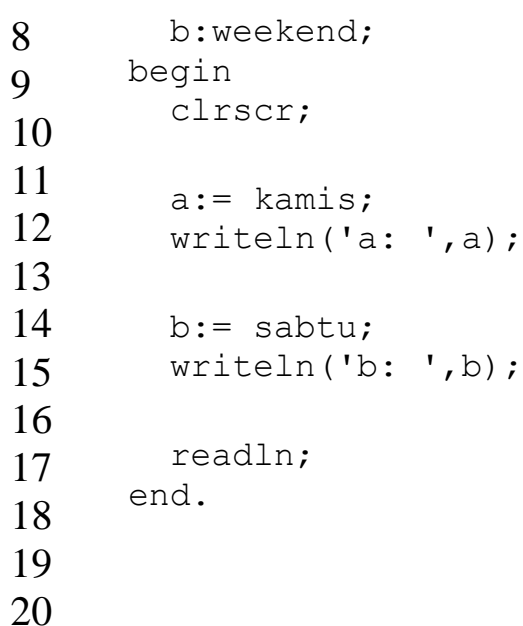

Contoh diatas saya ambil dari kode program dari tutorial tipe data enumeration, dimana saya mendefenisikan nama_hari sebagai tipe data enumerated. Namun kali ini saya membuat tipe data subrange hari_kerja dan weeken d dari nama_hari.

Konsep

penggabungan enumerated dan subra nge ini mungkin cukup rumit, tapi jika anda telah memahami tutorial sebelumnya tentang enumeration, saya rasa bisa memahami cara kerja kode program diatas. Silahkan diubah-ubah dan lihat bagaimana hasilnya.

\section{ID SECURITY QWTD4452377-ASP-5244107 \\ D. KESIMPULAN}

Subjangkauan merupakan suatu tipe yg menyatakan suatu jangkauan nilai dari suatu tipe yg sudah ada. Jangkauan nilai ditentukan oleh nilai terkecil dan nilai terbesar.Antara nilai terkecil dan nilai terbesar dipisahkan oleh tanda subjangkauan (..).Bentukpendeklarasian:TYPEnama _type $=$ nilai_terkecil...nilai_terbesar;S 
ubjangkauan tdk dapat diterapkan untuk tipe real. Semua tipe ordinal bisa dipakai.

Tidak jarang terjadi batas nilai yang mungkin untuk suatu peubah merupakan bagian (subjangkauan) dari tipe data yang telah didefinisikan

\section{E. DISKUSI}

\section{F. REFERENCE}

[1] O. M. Febriani and A. S. Putra, "Sistem Informasi Monitoring Inventori Barang Pada Balai Riset Standardisasi Industri Bandar Lampung," J. Inform., vol. 13, no. 1, pp. 90-98, 2014.

[2] A. S. Putra, "Paperplain: Execution Fundamental Create Application With Borland Delphi 7.0 University Of Mitra Indonesia," 2018.

[3] A. S. Putra, "2018 Artikel Struktur Data, Audit Dan Jaringan Komputer," 2018.

[4] A. S. Putra, "ALIAS MANAGER USED IN DATABASE DESKTOP STUDI CASE DB DEMOS."

[5] A. S. Putra, "COMPREHENSIVE SET OF PROFESSIONAL FOR DISTRIBUTE COMPUTING."

[6] A. S. Putra, "DATA ORIENTED RECOGNITION IN BORLAND DELPHI 7.0."

[7] A. S. Putra, "EMBARCADERO DELPHI XE 2 IN GPUPOWERED FIREMONKEY APPLICATION."

[8] A. S. Putra, "HAK ATAS
KEKAYAAN INTELEKTUAL DALAM DUNIA TEKNOLOGY BERBASIS REVOLUSI INDUSTRI 4.0."

[9] A. S. Putra, "IMPLEMENTASI PERATURAN PERUNDANGAN UU. NO 31 TAHUN 2000 TENTANG DESAIN INDUSTRI BERBASIS INFORMATION TECHNOLOGY."

[10] A. S. Putra, "IMPLEMENTATION OF PARADOX DBASE."

[11] A. S. Putra, "IMPLEMENTATION OF TRADE SECRET CASE STUDY SAMSUNG MOBILE PHONE."

[12] A. S. Putra, "IMPLEMENTATION PATENT FOR APPLICATION WEB BASED CASE STUDI WWW. PUBLIKLAMPUNG. COM."

A. S. Putra "IMPLEMENTATION SYSTEM FIRST TO INVENT IN DIGITALLY INDUSTRY."

[14] A. S. Putra, "MANUAL REPORT \& INTEGRATED DEVELOPMENT

ENVIRONMENT BORLAND DELPHI 7.0."

[15] A. S. Putra, "PATENT AS RELEVAN SUPPORT RESEARCH."

[16] A. S. Putra, "PATENT FOR RESEARCH STUDY CASE OF APPLE. Inc."

[17] A. S. Putra, "PATENT PROTECTION FOR APPLICATION INVENT."

[18] A. S. Putra, "QUICK REPORT IN

PROPERTY 
Sist. Inf. dan Manaj. Basis Data), vol. 1, no. 1, pp. 21-30, 2018.

[27] A. S. Putra, H. Sukri, and K. Zuhri, "Sistem Monitoring Realtime Jaringan Irigasi Desa (JIDES) Dengan Konsep Jaringan Sensor Nirkabel," IJEIS (Indonesian J. Electron. Instrum. Syst., vol. 8, no. 2, pp. 221-232.

[28] D. P. Sari, O. M. Febriani, and A. S. Putra, "Perancangan Sistem Informasi SDM Berprestasi pada SD Global Surya," in Prosiding Seminar Nasional Darmajaya, 2018, vol. 1, no. 1, pp. 289-294.

[23] A. S. Putra, "ZQUERY CONNECTION IMPLEMENTED

PROGRAMMING STUDI CASE PT. BANK BCA Tbk."

[24] A. S. Putra, D. R. Aryanti, and I. Hartati, "Metode SAW (Simple Additive Weighting) sebagai Sistem Pendukung Keputusan Guru Berprestasi (Studi Kasus: SMK Global Surya)," in Prosiding Seminar Nasional Darmajaya, 2018, vol. 1, no. 1, pp. 85-97.

[25] A. S. Putra and O. M. Febriani, "Knowledge Management Online Application in PDAM Lampung Province," in Prosiding International conference on Information Technology and Business (ICITB), 2018, pp. 181-187.

[26] A. S. Putra, O. M. Febriani, and B. Bachry, "Implementasi Genetic Fuzzy System Untuk Mengidentifikasi Hasil Curian Kendaraan Bermotor Di Polda Lampung," SIMADA (Jurnal 